\title{
Novel Porous Refractory Synthesized from Diatomaceous Earth and Rice Husk Ash
}

\author{
Nguyen Hoc Thang* \\ PhD. Eng., Faculty of Chemical Technology, Ho Chi Minh City University of Food Industry, Ho Chi \\ Minh City, Viet Nam
}

\begin{abstract}
Refractory materials are products used in thermal equipment to protect the fire and prevent heat loss to the outside environment. Thermal equipment such as driers, ceramic kilns, glass or metal furnaces and others always consume high heat in the combustion of the fuel. If the thermal equipments have a high heat loss which cause wastes of the fuel and increases production costs. Therefore, researchers are always looking for a solution to minimize heat loss for the kiln. In which, refractory materials significantly influence to the heat loss of the kiln and they have been studied a lot in recent years. This study focused on utilization of locally available raw materials to produce the novel porous refractory composites. The products have high porosity based on choosing the suitable raw materials and forming process. The refractory has high porosity and low thermal conductivity reponded to the requirements of saving energy for the thermal equipments. More important, the novel porous refractory products have high shape stability when observed by heating microscope in a range of room temperature to over $1400^{\circ} \mathrm{C}$.
\end{abstract}

Keywords: Diatomaceous earth, Rice husk ash, Porous Refractory, Heat loss, Thermal conductivity

*Author for Correspondence E-mail: thangnh@ hufi.edu.vn

\section{INTRODUCTION}

Refractory is a material that retains its physical and chemical properties at high temperature (over $1000^{\circ} \mathrm{C}$ ) for a long time and not deformed under mechanical load. Refractory materials are widely used in industries such as metallurgy, chemicals, thermal power plant, ceramic, glass, cement production and others. Refractory materials are limited in special process technologies to reduce heat loss of the furnaces. During the operation of the equipment, researchers always find solutions to increase the quality of refractory bricks, prolong the usage time of bricks in the kiln. This contributes to increasing equipment productivity, reduce heat consumption, increase quality and decrease prices of products [1-4].

Todays, there have been many novel refractory materials to meet the demands of technical progress. These are super-advanced materials used in supersonic aircraft technology, modern rockets, materials in nuclear reactors, in spacecraft and others. There are different ways to classify refractory materials known as:

According to the chemical and physical properties of the initial raw materials, refractory materials are classified into 3 main groups: acidic refractories (silica, aluminosilicate, and zirconia); basic refractories (magnesite, dolomite, magnesiachrome); and neutral refractories (carbon graphite, chromite, alumina) [5-9].

According to fusion temperature, refractory materials are classified into 3 main groups: Normal refractories with fire resistant temperature are in the range of $1580-1780^{\circ} \mathrm{C}$; High refractories with fire resistant temperature are in the range of $1780-2000^{\circ} \mathrm{C}$; Super refractories with fire resistant temperature are over $2000^{\circ} \mathrm{C}$.

In addition, refractory materials are also classified according to method of manufacture; 
shaped or unshaped; refractoriness; thermal conductivity [10-18].

Diatomaceous earth (DE) is a lightweight mineral with the density around 0.25-0.50 $\mathrm{ton} / \mathrm{m}^{3}$ formed million years ago by diatom algae groups. DE contains high silica (6097\%) with amorphous porous structure. There is a vast DE reserve available all over the world. The United States, China, and other countries have DE reserves of about 250, 110 and 550 million tons, respectively, up to 2012 [19]. In another report, total DE reserves of the world are around 918.9 million tons estimated before 2006 [20].

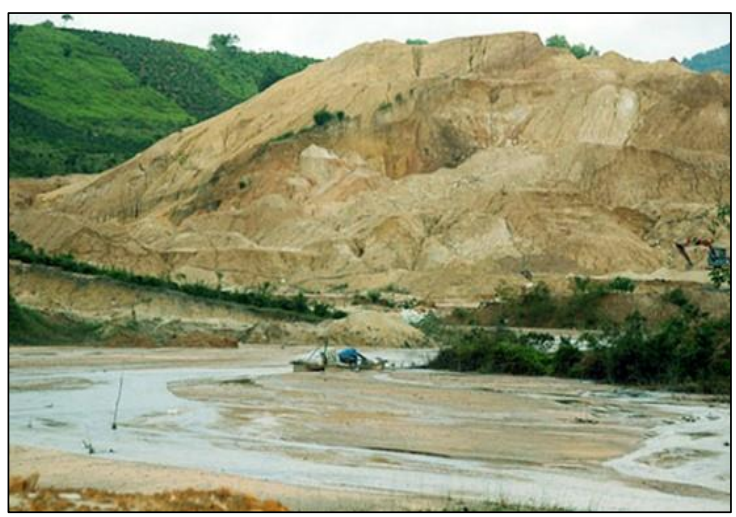

Fig. 1: Open-cast DE mine was exploited in Lam Dong province, Vietnam.

In Viet Nam, DE minerals are detected in many local known as Hai Phong city, Lam Dong, Phu Yen provinces and others with with different reserves. However, the raw material has low quality with a lot of impurities, especially clay minerals. Therefore, it will be costly to treat and use it like as the other diatomite in the global market. Hence, Vietnamese researchers are looking for the most appropriate solutions to exploit and use effectively this abundant resource [21].

Rice husk ash (RHA) is high - silica material made from burning rice husk. Rice husk takes up about $20 \%$ weight of rice and its compositions include $15-20 \% \quad \mathrm{SiO}_{2}$, the others are cellulose and lignin [22-23]. Therefore, after burning process, total weight of obtaining RHA is near $20 \%$ weight of rice husk. This characteristic mainly depends on burning conditions such as temperature, holding time. In 2011, rice production was over 700 million metric tons all over the world, where more than $90 \%$ belong to Asea countries such as China, India, Indonesia, Bangladesh, Vietnam, Burma, Thailand, and Philippines. Hence, total estimated RHA reserves are over 28 million metric tons every year [23-24].

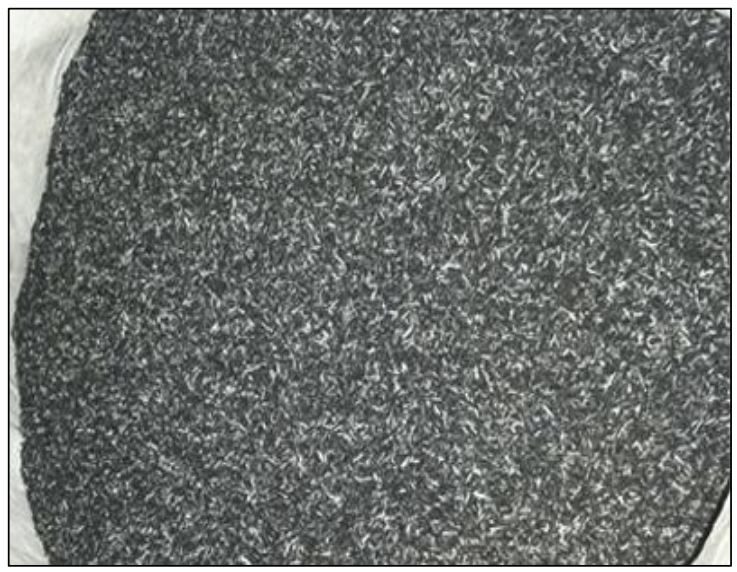

Fig. 2: Rice husk ash was Discharged after after the Boiler Combustion Process.

In Vietnam, rice husks are used as fuel for the drying of agricultural products or to burn boilers. The temperature of the burning process is only around $600^{\circ} \mathrm{C}$ in a very short time (less than 15 minutes) causing incomplete combustion of the ash. Therefore, the quality of rice husk ash is very low in order to be used it as a raw material for other industries. This ash is used only as a filler in fertilizer production or is poured directly onto the plant stumps. This reduces the value of the rice husk ash and wastes the high silica resources. However, RHA has high porosity and contains high silica in its chemical composition. Therefore, this study has utilized the rice husk ash as a main raw material supplying silica in the manufacture of refractory materials.

Besides, the study also used sawdust (SD) as an additive to aid the heating process and increase the porosity of the final product. Sawdust is a byproduct of the wood processing industry. The sawdust has the small particle size and uneven distribution so it has rarely used in life and only considered as waste to discharge in the environment. Sawdust has the potential to pose problems of health hazards. Wood dust is a human carcinogen and some 
types of wood and their dust contain toxins that can cause severe allergies. Therefore, using sawdust is a useful solution to both improve product porosity and save fuel for the burning process. Moreover, this solution also contributes to environmental protection by reducing solid waste throw away into the environment and community health protection.

That is the reason to proceed the study and obtain a refractory product with better than expected properties

\section{MATERIALS AND METHODOLOGY Materials and Mix Design}

The study used DE from Lam Dong province, Vietnam. This material has white or light yellow finely ground and passed through a $90 \mu \mathrm{m}$ sieve. It is then dried to prepare it for mixing and shaping.

RHA was used from the kiln of Loc Troi Group - formerly An Giang Plant Protection Joint Stock Company (AGPPJS) which is the leading agricultural manufacturer and service supplier in Vietnam market with the sustainable value chain from research, production, trading of seed products, crop chemicals and biological - organic products. Rice husk ash with the color of gray or dark, white was finely ground and passed through a $90 \mu \mathrm{m}$ sieve to prepare for the mixing and forming of products.

Sawdust was from a local wood production facility in Binh Chanh town, Ho Chi Minh city, Vietnam, which was dried at $110^{\circ} \mathrm{C}$ for 24 hours and passed through a $250 \mu \mathrm{m}$ sieve to prepare for the mixing and forming of products.

Table 1: Mix Design for Raw Materials in Porous Refractory (\% wt).

\begin{tabular}{|l|c|c|c|}
\hline \multirow{2}{*}{ Samples } & \multicolumn{3}{|c|}{ Raw materials } \\
\cline { 2 - 4 } \multicolumn{1}{|c|}{ M0 } & RHA & SD \\
\hline M5 & 50.0 & 50.0 & 0 \\
\hline M10 & 47.5 & 47.5 & 5.0 \\
\hline M15 & 45.0 & 45.0 & 10.0 \\
\hline M20 & 42.5 & 42.5 & 15.0 \\
\hline M25 & 40.0 & 40.0 & 20.0 \\
\hline M30 & 37.5 & 37.5 & 25.0 \\
\hline M35 & 35.0 & 35.0 & 30.0 \\
\hline
\end{tabular}

The mixtures were designed with changes of ratios sawdust, DE and RHA as shown in Table 1.

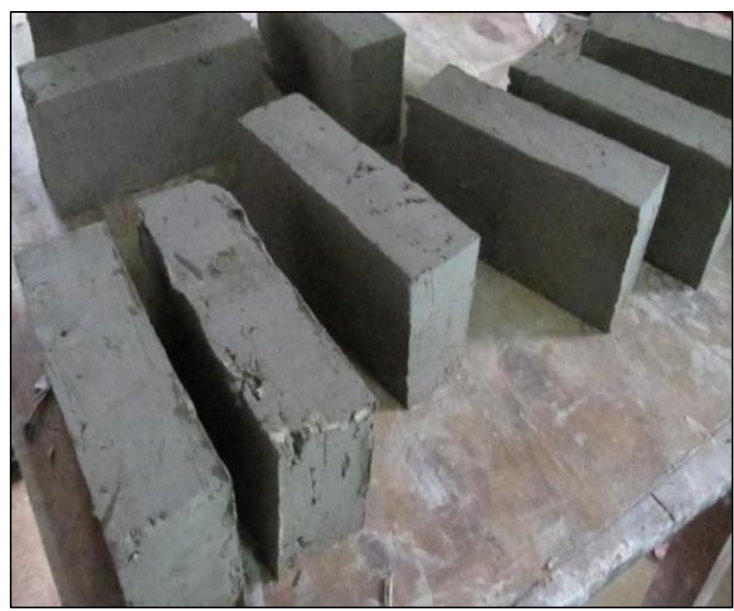

Fig. 3: The Refractory Samples after Forming.

Water was added with $40 \%$ of the mixtures to get the plasticity meals. It is noted that the samples with over $40 \%$ SD can not formed because the mixtures did not have the plasticity required for forming. The refractory samples were formed into bricks with sizes of 220x110x65 (mm) from the plasticity meals. The forming process was carried out with a pressure of $10 \mathrm{MPa}$ and obtained specimens as shown in Figure 3. These wet samples were dried naturally in a warehouse at a temperature about $30^{\circ} \mathrm{C}$ for 72 hours ( 3 days) and then dried in oven at $60^{\circ} \mathrm{C}$ for 24 hours (1 day). Finally, the dried samples were heated at $1200^{\circ} \mathrm{C}$ as mentioned below.

\section{Evaluation and Determination of the Heating Regime for Refractory Products}

In this study, the sample with 35\%SD (M35) was chosen to carry out for thermal analysis (DTA-TG) with the results shown in Figure 4.

The sample M35 was heated from room temperature $\left(25^{\circ} \mathrm{C}\right)$ to $1200^{\circ} \mathrm{C}$ with heating rate at $5^{\circ} \mathrm{C}$ /minute. During the heating process, the sample M35 had been decreased mass over $40 \%$ related to evaporation of physical absorbed water (drying); decompositions of organic matter including sawdust; dehydration of clay minerals; phase structure changes of quartz and aluminosilicate compounds and sintering process over $1100^{\circ} \mathrm{C}$. 


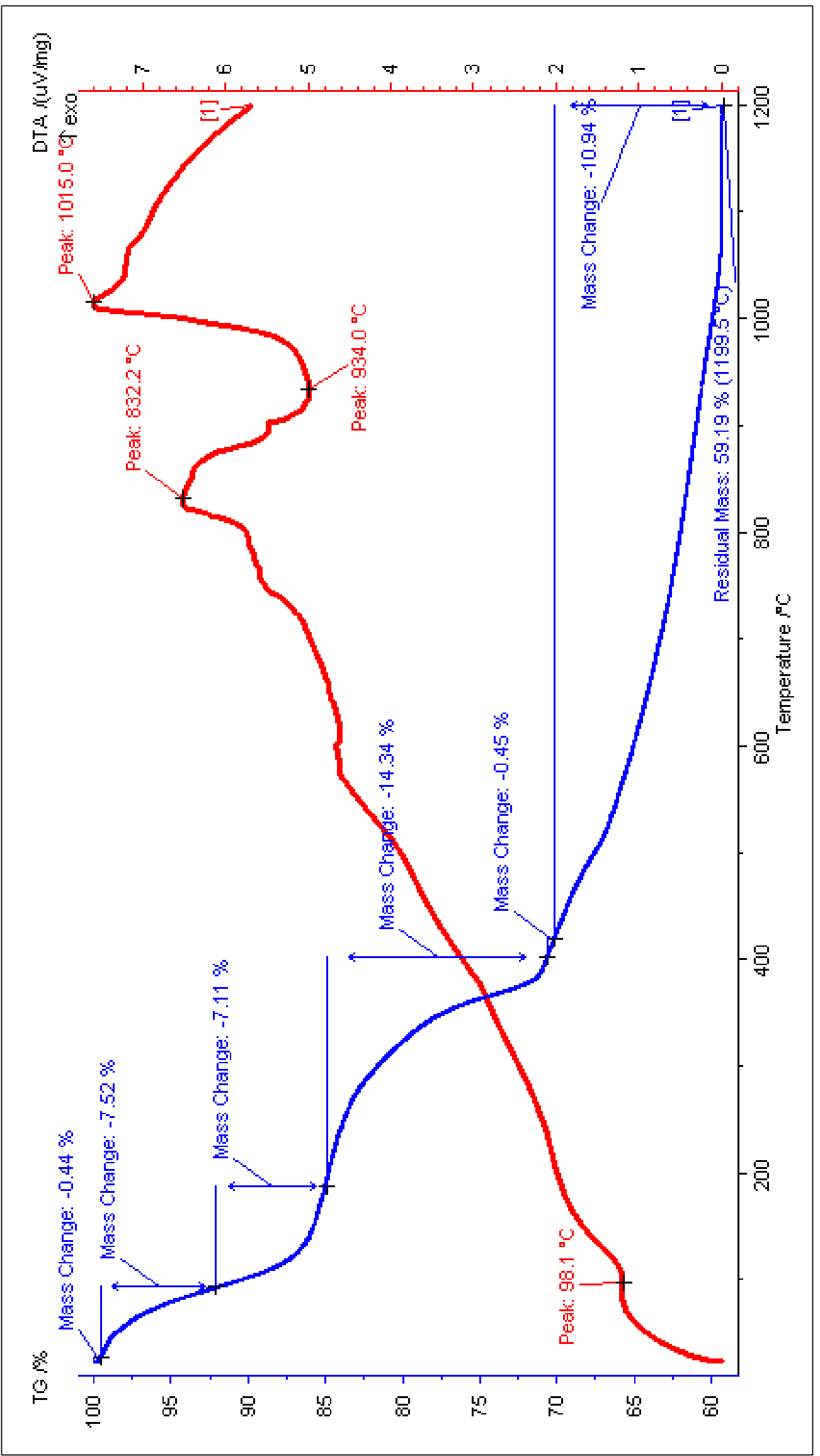

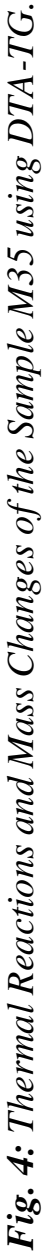


It is based on evaluations of DTA-TG, the study has provided a solution for the heating regime of the refractory specimens. The products were heated at $1200^{\circ} \mathrm{C}$ for 2 hours to ensure for completely sintering. From room temperature to $600^{\circ} \mathrm{C}$, there have been many physico-chemical reactions happened in combination with combustion and thermal decomposition of saw dust. Therefore, the heating rate should be slow at $1{ }^{\circ} \mathrm{C} /$ minute to avoid deformation of the specimens. From 600 to $1200^{\circ} \mathrm{C}$, there are phase structure changes of quartz and alumino-silicate compounds and sintering process, mass loss was around $5 \%$, the heating rate was adjusted at $2{ }^{\circ} \mathrm{C} /$ minute. The cooling process was carried out according to the rate of cooling of the furnace with cooled rate at $3^{\circ} \mathrm{C} /$ minute. The entire thermal regime of the porous refractory products is indicated by a heating curve diagram as sown in Figure 5. Finally, the refractory specimens manufactured (Figure. 6.) were tested for engineering and thermal properties. In which, the engineering properties included volumetric weight $\left(\mathrm{g} / \mathrm{cm}^{3}\right)$, porosity $(\%)$, bending and compressive strength (MPa); thermal properties were tested for thermal shrinkage (\%), thermal shock resistance (time), thermal conductivity (W/m.K).

\section{RESULTS AND DISCUSSION}

After cooled process, the specimens of refractory composite were removed from the furnace to test for the required properties. In this study, the samples were focused on testing for engineering and thermal properties.

\section{Engineering Properties of the Porous Refractory Composite}

The engineering properties of the products are physical and mechanical properties known as volumetric weight $\left(\mathrm{g} / \mathrm{cm}^{3}\right)$, porosity $(\%)$, bending and compressive strength (MPa).

Table 2: The Values of Volumetric Weight $\left(\mathrm{g} / \mathrm{cm}^{3}\right)$ and Porosity (\%) for the Porous

$$
\text { Refractory. }
$$

\begin{tabular}{|l|c|c|}
\hline \multirow{2}{*}{ Samples } & \multicolumn{2}{|c|}{ Engineering Properties } \\
\cline { 2 - 3 } & Volumetric Weight $\left(\mathbf{g} / \mathbf{c m}^{3}\right)$ & Porosity $(\%)$ \\
\hline M0 & 0.66 & 75.32 \\
\hline M5 & 0.61 & 74.28 \\
\hline M10 & 0.57 & 78.13 \\
\hline M15 & 0.53 & 81.64 \\
\hline M20 & 0.48 & 83.08 \\
\hline M25 & 0.44 & 86.76 \\
\hline M30 & 0.41 & 88.51 \\
\hline M35 & 0.37 & 92.45 \\
\hline
\end{tabular}

The novel refractory composites have the values of the volumetric weight from 0.37 to $0.66 \mathrm{~g} / \mathrm{cm}^{3}$ which have belonged to the group of lightweight materials. In addition, the porosity of the products is really high from 74.28 to $92.45 \%$ as shown in Table 2. This is explained that the porous refractory composites were formed from raw materials which have high porosity as known DE and RHA.

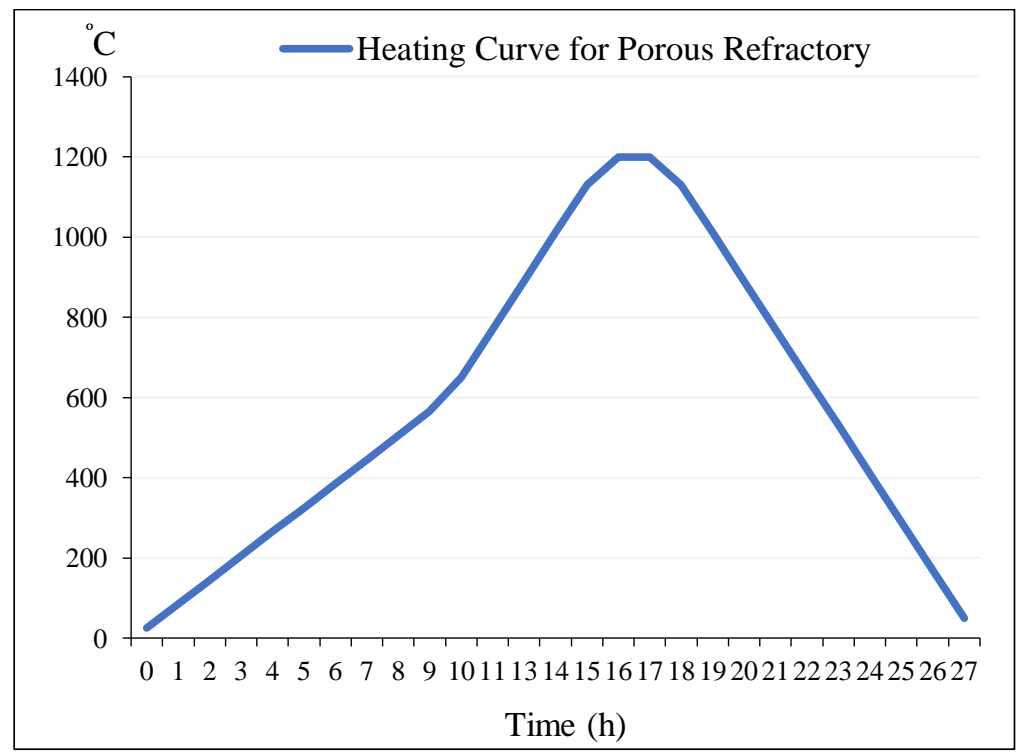

Fig. 5: The Heating Curve for the Porous Refractory from Diatomaceous Earth and Rice Husk Ash. 


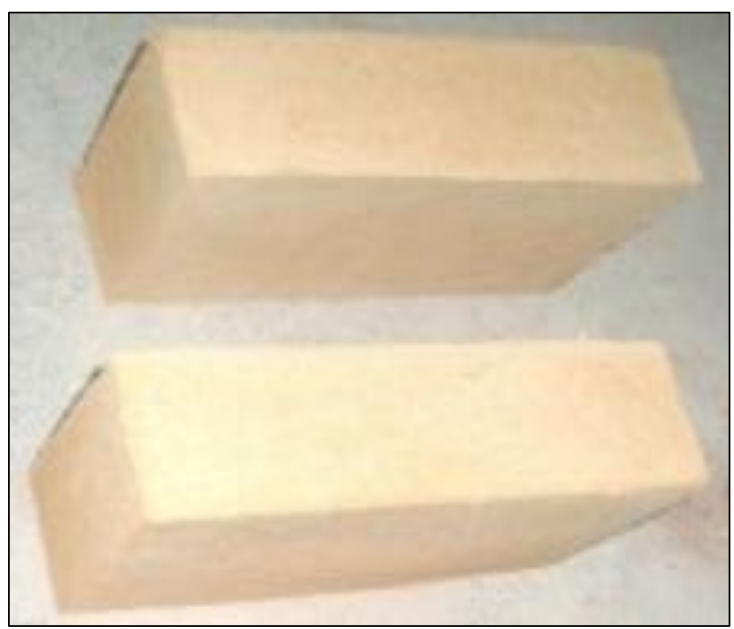

Fig. 6: The Porous Refractory Products of the Study after Heating at $1200^{\circ} \mathrm{C}$.

The second reason come from using sawdust which after combustion will reduce the mass of the material and leave more pores. Moreover, the water was added and water in clay minerals also has a role similar to sawdust.

In this research, the values of the volumetric weight decreased to $0.37 \mathrm{~g} / \mathrm{cm}^{3}$ when the sawdust ratios were increased to $35 \%$. This caused the porosity of the products was improved and reached to $92.45 \%$ as shown in Figure 7 . Therefore, the porous refractory composite with $35 \%$ sawdust (M35) has the lowest value of volumetric weight and the highest value of porosity.

Table 3: The values of Bending and Compressive Strength ( $\mathrm{MPa}$ ) for the Porous Refractory.

\begin{tabular}{|l|c|c|}
\hline \multirow{2}{*}{ Samples } & \multicolumn{2}{|c|}{ Mechanical Properties } \\
\cline { 2 - 3 } & $\begin{array}{c}\text { Bending strength } \\
(\mathrm{MPa})\end{array}$ & $\begin{array}{r}\text { Compressive Strength } \\
(\mathrm{MPa})\end{array}$ \\
\hline M0 & 1.78 & 17.35 \\
\hline M5 & 1.75 & 17.24 \\
\hline M10 & 1.72 & 17.03 \\
\hline M15 & 1.72 & 16.84 \\
\hline M20 & 1.70 & 16.68 \\
\hline M25 & 1.68 & 16.41 \\
\hline M30 & 1.66 & 16.11 \\
\hline M35 & 1.61 & 15.78 \\
\hline
\end{tabular}

The porous refractory specimens were tested for mechanical strength with the strength values decreased when the increase of sawdust ratios or porosity. In which, the values of bending strength were gone down to $1.61 \mathrm{MPa}$ from $1.78 \mathrm{MPa}$ and the values of compressive strength were reduced from $17.35 \mathrm{MPa}$ to 15.78 MPa as shown in Table 3 and Figure 8. The mechanical strength of the product is obtained by the solid phase reactions, diffusion and sintering among solid powders together during the heating process at $1200^{\circ} \mathrm{C}$.

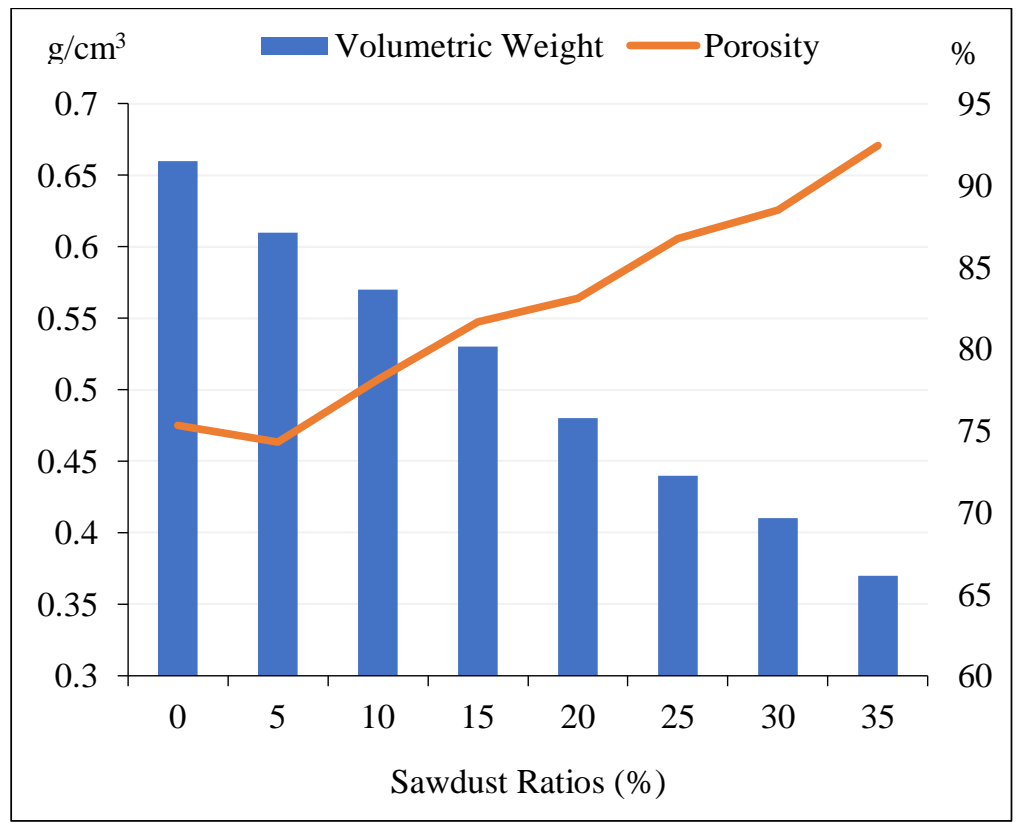

Fig. 7: Relationships among Sawdust Ratios with Volumetric Weight and Porosity of the Porous Refractory Composite. 


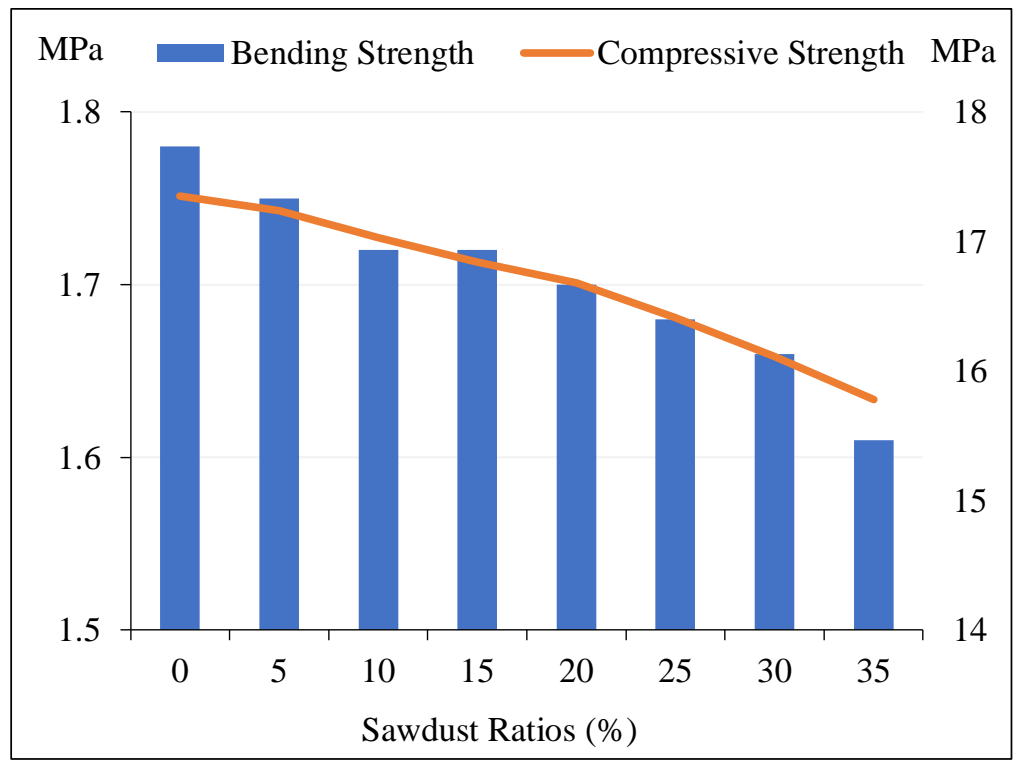

Fig. 8: Relationships among Sawdust Ratios with Mechanical Strength of the Porous Refractory.

\section{Thermal Properties}

The thermal properties of porous refractory composites were carried out with the experiments for testing of thermal shock resistance (time), thermal conductivity $(\mathrm{W} / \mathrm{m} . \mathrm{K})$, shape factor and changes of area using heating microscope for sample M35.

Table 4: The Values of Thermal Properties for the Porous Refractory.

\begin{tabular}{|l|c|c|}
\hline \multirow{2}{*}{ Samples } & \multicolumn{2}{|c|}{ Thermal Properties } \\
\cline { 2 - 3 } & $\begin{array}{c}\text { Thermal Shock } \\
\text { Resistance (Time) }\end{array}$ & $\begin{array}{c}\text { Thermal Conductivity } \\
\text { (W/m.K) }\end{array}$ \\
\hline M0 & 78 & 0.1035 \\
\hline M5 & 75 & 0.1024 \\
\hline M10 & 72 & 0.1003 \\
\hline M15 & 72 & 0.0984 \\
\hline M20 & 70 & 0.0968 \\
\hline M25 & 68 & 0.0941 \\
\hline M30 & 66 & 0.0911 \\
\hline M35 & 61 & 0.0878 \\
\hline
\end{tabular}

In this study, the tests of thermal shock resistance were conducted at $1000^{\circ} \mathrm{C}$ with the results over 61 times for all of the specimens. These values are higher than comparable products on the market and meet the requirements of the TCVN standard (TCVN 6530-4:1999 and TCVN 6530-7:2000) on refractory materials. It is noted that the samples for testing thermal shock resistance were prepared in Seger cone. In specially, the higher the thermal shock resistance of the sample is, the smaller the porosity is. Because when heated, the sintering process was still continuously happened which caued the sample with a high porosity had strong arrangement and disturbance and the seger cone was easily deformed.

The porous refractory composites have really low values of thermal conductivity from 0.0878 to $0.1035 \mathrm{~W} / \mathrm{m} . \mathrm{K}$. The values significantly reduced and reached to the lowest values at $0.0878 \quad \mathrm{~W} / \mathrm{m} . \mathrm{K}$ corresponding to increase of porosity in the materials as shown in Table 4 and Figure 8. The low thermal conductivity of the refractory product will ensure heat savings for the furnaces with high efficiency to the fuel burning process. This is a solution with high economic efficiency for industries that use thermal equipment.

More specifically, this study used a heating microscope to observe changes in the product shape (sample M35) at high temperatures. Figure 9 shows the porous refractory had no change of the shape from room temperature to $1110^{\circ} \mathrm{C}$ as indicated on the line $\mathrm{S}$. The sintering process occurred over $1110^{\circ} \mathrm{C}$ upto $1282^{\circ} \mathrm{C}$ as showed on the line A. At $1282^{\circ} \mathrm{C}$, the sintering caused shrinkage of the sample with shape factor at 0.738 , changes of area at $65.1 \%$, height at $78.7 \%$, and width of $86.6 \%$. 


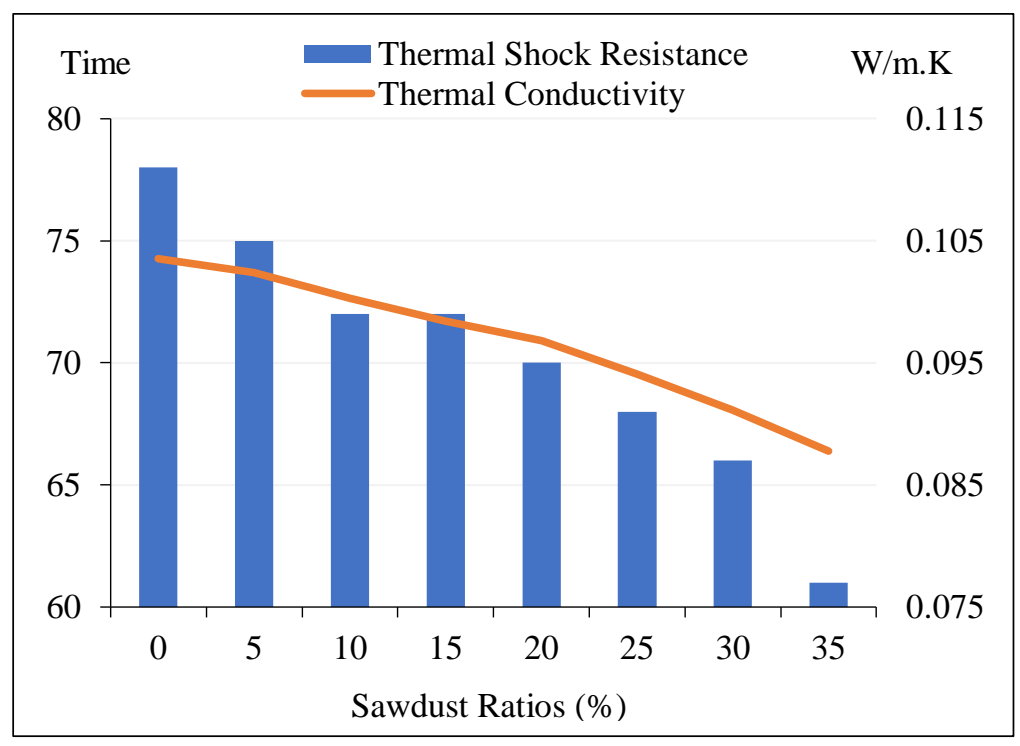

Fig. 8: Relationships among Sawdust ratios with Thermal Shock Resistance, Thermal Conductivity of the Porous Refractory Composites.

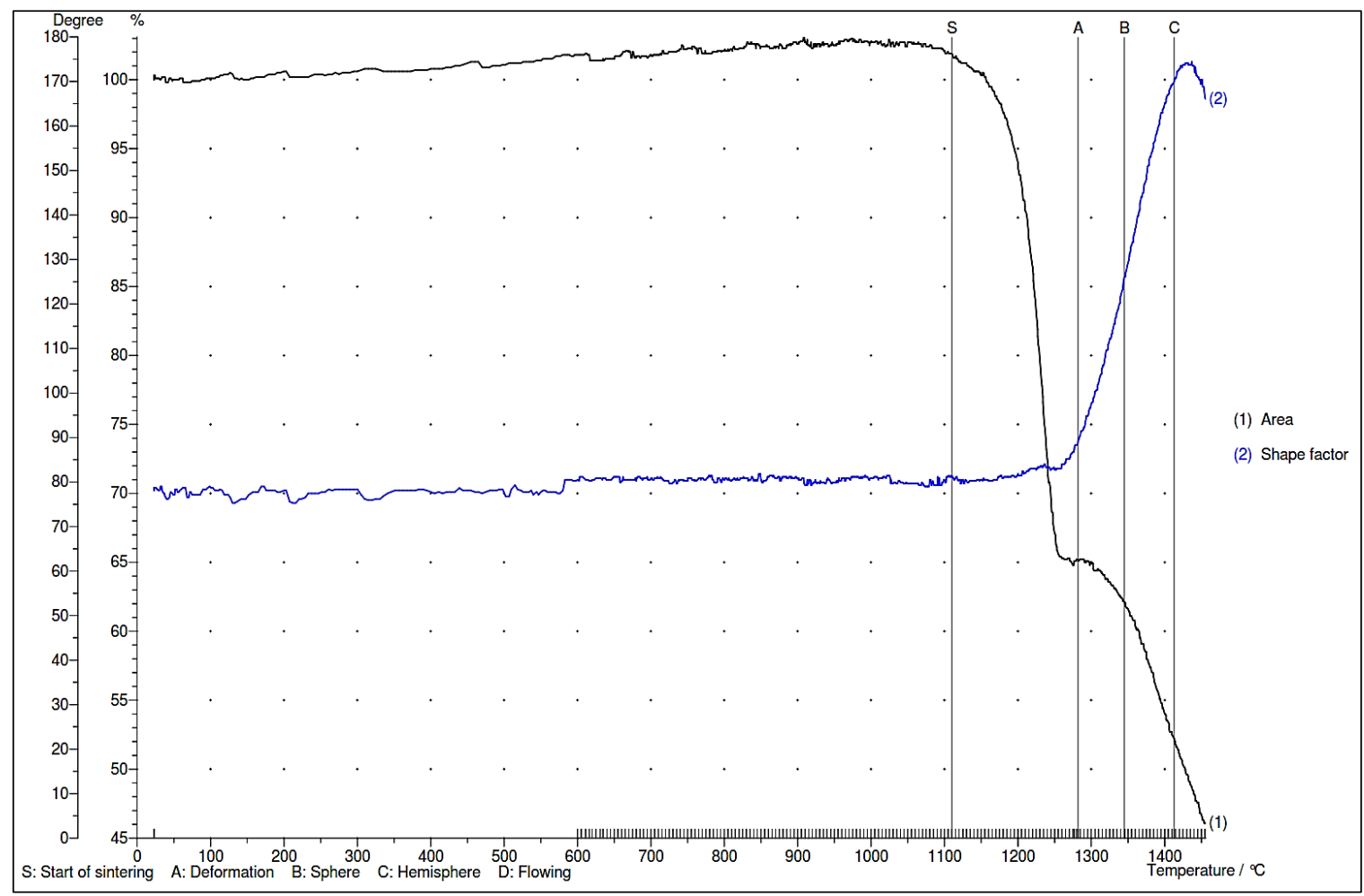

Fig. 9: Changes for the Product Shape (Sample M35) Observed by Heating Microscope.

Over $1282^{\circ} \mathrm{C}$, the sample was deformation of shape as known sphere at $1345^{\circ} \mathrm{C}$ (the line $\mathrm{B}$ ), hemisphere at $1413^{\circ} \mathrm{C}$ (the line $\mathrm{C}$ ) and flowing at higher temperature (the line $\mathrm{D}$ ).

\section{CONCLUSION}

This research utilized resource of abundant diatomite but low quality in combination with rice husk ash and sawdust to produce porous refractory products. Both rice husk ash and sawdust are solid wastes from agroprocessing and wood production industries. Therefore, using them as raw materials for refractory production is a useful solution and has many economic and environmental benefits. 
The refractory products have engineering properties responded to the requirements of porous materials group with low volumetric wight and high porosity. Moreover, the tests of thermal properties also showed the novel porous refractory composites have high thermal shock resistance and low thermal conductivity. These features allows them to work in the harshest conditions of high temperature environments.

Further research should be carried out for characterizing microstructure of the novel porous refractory composites to to gain a deeper understanding of the material. In addition, future studies should also conduct tests and calculate the heat loss during the heating process for thermal equipment using this product.

\section{NOMENCLATURE}

$D E \quad$ : Diatomaceous Earth

RHA : Rice Hush Ask

$S D$ : Sawdust

DTA : Differential Thermal Analysis

$T G$ : Thermogravimetric

\section{REFERENCES}

1. Kingery, W.D., Bowen, H.K., Uhlmann, D.R., Introduction to Ceramic, $2^{\text {nd }}$ edition, Wiley, 1976.

2. Groover, P. Mikell, Fundamentals of Modern Manufacturing: Materials, Processes, and Systems, John Wiley \& Sons, 2010.

3. Eiji Horie, Ceramic fibre insulation theory and practice-The energy conservation center, Tokyo, 1997.

4. Sadik, C., El Amrani, I.E., Albizane, A., Recent advances in silica-alumina refractory: A review, Journal of Asian Ceramic societies, 2014, 2(2), 83-96.

5. Ruh, E., Physical Properties of Refractories, Ceramics in Severe Environments. Materials Science Research, 1971, 5, 404-410.

6. Černý, R., Poděbradská, J., Toman, J., Jiřičková, M., Mňahončáková, E., Rovnaníková, P., Bayer, P., High Temperature Properties of Fibre Reinforced Cement Composites, Proceedings of the International
Conference on Application of Codes, Design and Regulations, 2005, 403-412.

7. Nguyen, H.T., Dang, T.P., Using activated diatomite as adsorbent for treatment of arsenic contaminated water, Key engineering materials, 2020, 850, 16-21.

8. Deer, W.A., Howie, R.A., Zussman, J., An introduction to the rock-forming minerals, 2nd edition, Harlow: Longman, 1992.

9. Do, Q.M., Nguyen, T.T.L., Pham, V.T.H.Q., Nguyen, H.T., The Novel Crystalline Glaze for Decoration of Ceramic Pottery, Materials science forum, 2020, 987, 165-170

10. Ravichandran, G., Halloysite nanotubes-A novel reinforcing material for future applications, Journal of polymer and composites, 2019, 7(1), 34-40

11. Patnaik, S.C., Maharana, S., Adak, S., Mishra, A., A Study on the Sintering Behavior of $\mathrm{Al}_{2} \mathrm{O}_{3} / \mathrm{Y}_{2} \mathrm{O}_{3}$ Doped $\mathrm{ZrO}_{2}$ Composites, Journal of polymer and composites, 2014, 2(1), 1-8.

12. Nguyen, H.T., Gallardo, S.M., Bacani, F.T., Hirofumi Hinode, Do, .M., Do, M.H., Promentilla, M.A.B., Evaluating thermal properties of geopolymer produced from red mud, rice husk ash and diatomaceous earth, ASEAN engineering journal, 2015, 4(1) 51-65.

13. Nguyen, H.T., Pham, T.K., Abdullah, M.M.A.B., Lightweight heat resistant geopolymer-based materials synthesized from red mud and rice husk ash using sodium silicate solution as alkaline activator, MATEC Web of Conferences, 2017, 97, 01119.

14. Christopher Bryant, Refractory Materials: Characteristics, Properties and Uses, Nova science publishers, 2018

15. Wu, L., Li, C., Li, H., Wang, H., Yu, W., Chen, K., Zhang, X., Preparation and characteristics of porous anorthite ceramics with high porosity and hightemperature strength, International Journal of Applied Ceramic Technology, 2019, 17 (3), 963-973.

16. Chaudhuri, S.P., Chatterjee, M.K., Spalling Characteristics of Aluminosilicate Refractories in Relation to their Chemical and Mineralogical Composition, Transactions of the Indian Ceramic Society, 2014, 28 (2), 44-51. 
17. Xiong, J.Q., Peng, Y.T., Xie, D.Y., Mao, X.S., The Characteristics of Silica-Sol Combining Refractories, Advanced Materials Research, 2011, 396-398, 288-291.

18. Prasunjit Sengupta, Refractories for the Cement Industry, Springer International Publishing, 2020.

19. Crangle, R.D.Jr., Diatomite. U.S. Geological Survey, Mineral Commodity Summaries, 2012, 52-53.

20. Indian Minerals Yearbook 2011 (Part II), Diatomite (Advanced Release), $50^{\text {th }}$ edition, Government of India, Ministry of Mines, Indian Bureau of Mines, 2012.

21. Nguyen, H.T., Evaluation on Formation of Aluminosilicate Network in TernaryBlended Geopolymer Using Infrared Spectroscopy, Solid State Phenomena, 2019, 296, 99-104
22. Chandra, S., (1997). Waste materials used in concrete manufacturing. Published by Noyes Publications in USA.

23. Siddique, R. and Khan, M.I., Supplementary Cementing Materials. Engineering Materials, Springer-Verlag Berlin Heidelberg, 2011.

24. Nguyen, H.T., Le, T.N., Pham, V.T.H.Q., Dang, T.P., Dao, T.K., Nguyen, V.P., Development of heat resistant geopolymer-based materials from red mud and rice husk ash, AIP Conference Proceedings, 2018, 1954 (1), 040005.

\section{Cite this Article}

Nguyen Hoc Thang. Novel Porous Refractory Synthesized from Diatomaceous Earth and Rice Husk Ash. Journal of Polymer \& Composites. 2020; 8(2): 128-137p. 